\title{
Two New Species of the Genus Thoracophorus Motschulsky, 1837 (Coleoptera: Staphylinidae, Osoriinae) with Remarks on Ecology of the Genus in the Neotropical Region
}

\author{
Ulrich Irmler \\ Ecology-Centre, University of Kiel, Olshausenstrasse 40, 24098 Kiel, Germany \\ Correspondence should be addressed to Ulrich Irmler, uirmler@ecology.uni-kiel.de \\ Received 5 November 2009; Revised 8 January 2010; Accepted 1 February 2010 \\ Academic Editor: Christopher Carlton \\ Copyright (c) 2010 Ulrich Irmler. This is an open access article distributed under the Creative Commons Attribution License, which \\ permits unrestricted use, distribution, and reproduction in any medium, provided the original work is properly cited.

\begin{abstract}
The new species Thoracophorus venezuelanus and T. silvaticus are described. The ecological information from labels and that produced by more detailed studies in Central Amazonia indicate that tree canopies and tree trunks are main habitats of Thoracophorus species, and that many species might be associated with ants or termites.
\end{abstract}

\section{Introduction}

New species of the genus Thoracophorus have been found in recent collections of Volker Assing and colleagues of the Natural History Museum, Lawrence, Kansas.

A review on the species richness of the genus in the Neotropical region is given based on the numbers and species in my database, which includes 1186 specimens determined to species from different museums. Additionally, material collected by myself in 1971 and 1972 was analysed. This material was collected in three inundation forests near Manaus [1], but could not be identified to the species level at that time. Two years ago I received the rove beetle material from J. Adis ( $\dagger$ ) for identification; it was collected by different methods in a Varzea forest near Manaus, it also included two Thoracophorus species. Thus, this study has the following aims: (1) descriptions of new species and (2) analysis of the overall ecology of the genus and the specific ecology of single species.

\section{Material and Methods}

The material includes the new species derived from the collection of Volker Assing (VAC), Hannover, Germany, and from the Snow Entomological Museum Collections of the University of Kansas Natural History Museum, Lawrence, USA (SEMC). I thank V. Assing and J. S. Ashe ( $\dagger$ ), formerly
University of Kansas, for lending the material and for the deposition of some paratypes for my collection. Types are deposited in these collections and in my own collection (UIC). The types deposited now in private collections will be deposited in public collections later. Length was measured along the middle of the tagmata and width across widest part of tagmata. Total length measures cover the fore-body and length of the abdominal tergites without intersegmental spaces.

Ecological information was derived from the 1186 Thoracophorus specimens included in my database. Specimens were identified over the past 25 years and originated from different museums and private collections [2-4]. In addition, the rove beetle material of J. Adis was studied. This material was collected between April 1981 and March 1982 using different methods on Ilha de Marchanteria $\left(58^{\circ} 58^{\prime} \mathrm{W}\right.$, $3^{\circ} 15^{\prime} \mathrm{S}$ ), an island in the Rio Solimões approximately $10 \mathrm{~km}$ upstream from the inflow of the Rio Negro. The material included 16 samples collected at 4 sites by canopy fogging, 5 replicate samples at two sites each by trapping at tree trunks, 21 replicate samples of a Kempson heat extraction of litter, 3 ground emergence traps containing a pitfall trap, and 7 pitfall traps [5].

My own samples that were collected during the dry season between September 1971 and April 1972 in three inundation forests near Manaus were reinvestigated. These forests are directly influenced by the white waters of the 


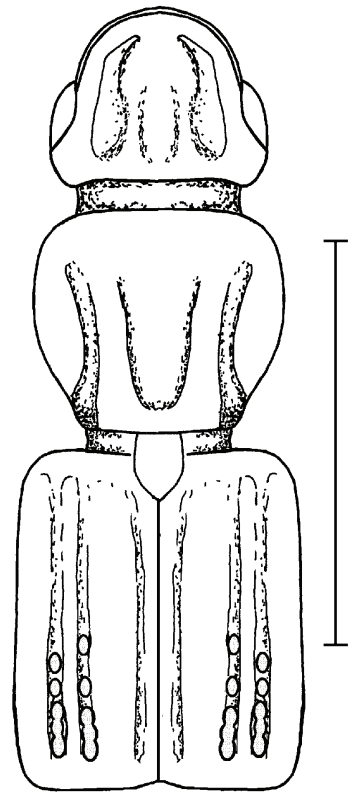

(a)

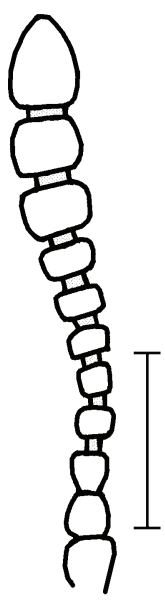

(b)
Figure 1: Fore body (a), antenna (b) of Thoracophorus simplex (scale bar (a) $0.5 \mathrm{~mm}$, (b) $0.1 \mathrm{~mm}$ ).

Rio Solimões (Ilha do Curarí), by the mixed waters (Lago Janauarí), and by the black waters of the Rio Negro (Rio Tarumã Mirím). Further information about sampling dates and methods is given in Irmler [1]. Abundance of Thoracophorus guadalupensis Cameron, 1913 was measured by hand-sorting from $0.1 \mathrm{~m}^{2}$ leaf litter collected at sites located in a flooding gradient in the three forests in this investigation.

\section{Description of the New Species}

3.1. Thoracophorus venezuelanus n.sp. (see Figures: 2(a)2(c), 4(c)-4(d)).

Material. Holotype: Venezuela: Carabobo, Mun. Bejuma, El Maquero $\left(10^{\circ} 15.90 \mathrm{~N}, 68^{\circ} 17.60 \mathrm{~W}\right), 1200 \mathrm{~m}$ elevation, male, 21.01.2007, leg. L. Brachat (VAC). Paratypes: 1 male, 4 females with the same data as for the holotype (VAC, UIC).

Diagnosis. T. venezuelanus is closely related to T. simplex (Figures 1(a) and 1(b), 4(a) and 4(b)) due to its small size and the weakly developed elytral carinae, pronotal depressions, and head elevations. T. venezuelanus is slightly larger than T. simplex Wendeler, 1930 that is only $1.5 \mathrm{~mm}$ in size. Distinct differences are found in the antennae. The penultimate antennomeres in T. simplex are only twice as wide as long, whereas they are three times as wide as long in T. venezuelanus. Moreover, the elytra are totally polished in $T$. simplex, but matte in T. venezuelanus. The aedeagus provides no valuable differentiating characters.

Description. Length: 1.8-2.0 mm. Colour: light red, head and pronotum slightly darker. Head: $0.25 \mathrm{~mm}$ long, $0.33 \mathrm{~mm}$ wide; eyes distinctly prominent; temples short and abruptly narrowed to neck; disc with a moderately deep depression on each side of the middle; finely punctate, but with deeper and larger punctures in paired depressions; without usually developed pair of longitudinal elevations at centre of disc; surface shiny and with extremely weak longitudinal microsculpture. Antennae short; as long as head and half of pronotum combined; first two antennomeres thick; following four antennomeres distinctly smaller; 3rd antennomere conical, 4 th to 6 th antennomere quadrate; antennomeres 8 to 10 at least 3 times as wide as long. Pronotum: $0.27 \mathrm{~mm}$ long, $0.33 \mathrm{~mm}$ wide; sides nearly parallel in anterior half; front angles obtusely rounded; in dorsal aspect, lateral margin visible in posterior half only; lateral furrows weakly depressed and nearly obsolete in the anterior half; central depression also weakly developed; with extremely fine punctation and longitudinal microsculpture; surface shiny except in the lateral and central depressions with a slightly more distinct microsculpture and thus matter surface. Elytra: $0.48 \mathrm{~mm}$ long, $0.37 \mathrm{~mm}$ wide; with fine longitudinal carinae; intercarinate space with dense and deep microsculpture; surface matte.

Etymology. The specific name is derived from the country in which the species was found.

3.2. Thoracophorus silvaticus n.sp. (see Figures: $3(a)-3(c)$, $4(\mathrm{e})$ and $4(\mathrm{f}))$.

Material. Guyana: Region B, Iwokrama forest, Turtle Mt., base camp $\left(4^{\circ} 43.5^{\prime} \mathrm{N}, 58^{\circ} 43.5^{\prime} \mathrm{W}\right), 50 \mathrm{~m}$ elevation, male, 1 Jun. 2001, leg. R. Brooks, Z. Falin, \#GUY1BF01 100, collected under bark (holotype, SEMC). Paratypes: Peru: Madre de Dios, Pentiacolla Lodge, $8 \mathrm{~km}$ NE Mirador, Alto Madre do Dios River $\left(12^{\circ} 38.23^{\prime} \mathrm{S}, 71^{\circ} 16.23^{\prime} \mathrm{W}\right), 950 \mathrm{~m}$ elevation, female, 24. Oct. 2000, leg. R. Brooks, \#PERU1B00 083, collected under bark (SEMC); Suriname: Marowijne, Palumeu $\left(3^{\circ} 20.56^{\prime} \mathrm{N}, 55^{\circ} 26.18^{\prime} \mathrm{W}\right)$, ca 169 m elevation, male, 8. Jul. 1999, leg. Z.H. Falin, \#SUR1F99 182, collected in splintered log (pyrethrum fogging) (UIC); Saramacca West Suriname Road, $178 \mathrm{~km}$, WSW Zanderij Airport $\left(4^{\circ} 59.6^{\prime} \mathrm{N}\right.$, $\left.56^{\circ} 18.48^{\prime} \mathrm{W}\right), 25 \mathrm{~m}$ elevation, female, 13. Jun. 1999, leag. Z. Falin, \#SUR1F99 068, collected under bark (UIC).

Diagnosis. T. silvaticus can be distinguished by its characteristic colour and the triangular shape of the head. It resembles T. bruchi Bernhauer, 1933, T. sahlbergi Irmler, 1985, and T. susannae Irmler, 2001 by the shape of the pronotum with the strong emargination in front of the posterior angles. The overall shape is similar to T. columbinus Irmler, 2001, but the pronotal emargination in T. columbinus is less developed. Moreover, differences to T. susannae are also found in the more or less even lateral pronotal margin, although an indistinct denticulation can be developed in $T$. silvaticus. However, it is never as distinct as in T. susannae.

Description. Length: $2.4 \mathrm{~mm}$. Colour: light red; head at temples darker, on small parts nearly black; elytra darkened to posterior edge; legs and antennae yellow. Head: $0.25 \mathrm{~mm}$ long, $0.40 \mathrm{~mm}$ wide; shaped like a triangle with slightly rounded sides; temples behind eyes short, tooth-like prominent; directly narrowed to distinct neck; eyes prominent; central elevations indistinct and short; lateral elevations absent; without punctation, but with distinct and dense 


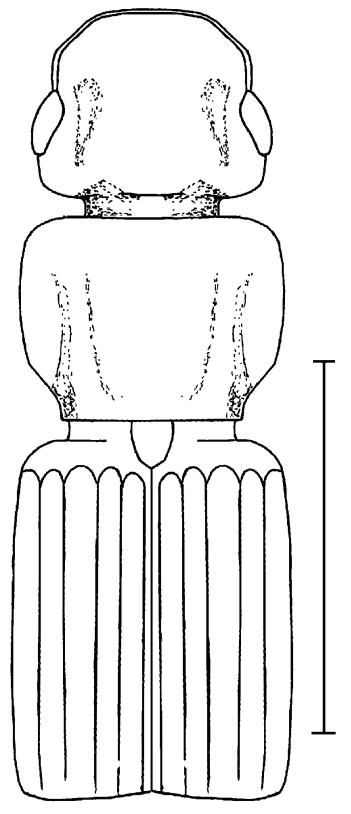

(a)

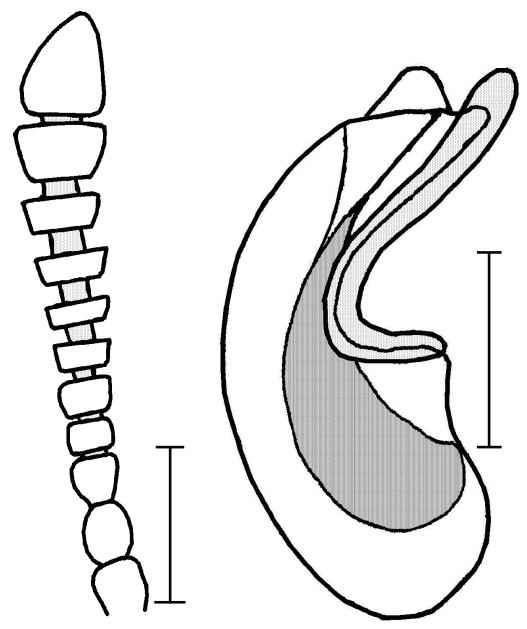

(b)

(c)

Figure 2: Fore body (a), antenna (b), and aedeagus (c) of T. venezuelanus (scale bar (a) $0.5 \mathrm{~mm}$, ((b and c) $0.1 \mathrm{~mm}$ ).

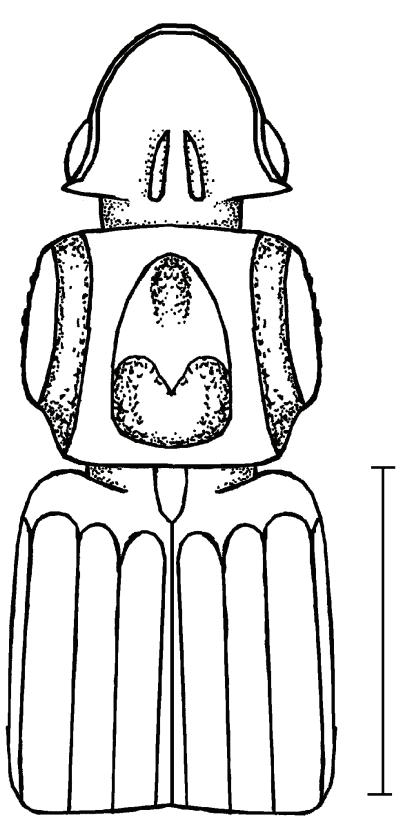

(a)

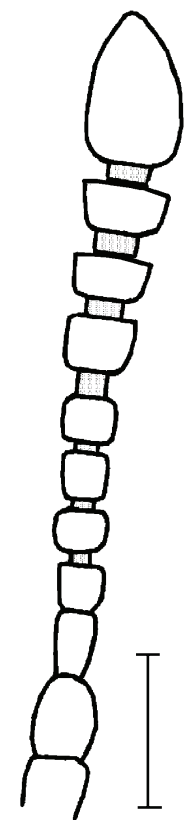

(b)

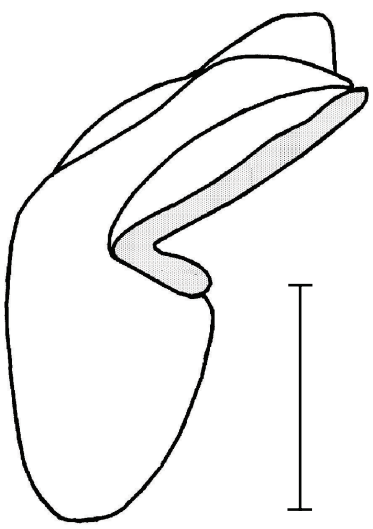

(c)

Figure 3: Fore body (a), antenna (b), and aedeagus (c) of T. silvaticus (scale bar (a) $0.5 \mathrm{~mm}$, ((b and c) $0.1 \mathrm{~mm}$ ).

microsculpture; surface matte. Antennae as long as head and half of pronotum combined; with antennomeres 1 and 2 thicker than following antennomeres; 2nd antennomere oblong, 3rd conical; antennomeres 4 to 6 quadrate, following antennomeres increasing in width and wider than long; penultimate antennomere twice as wide as long. Pronotum: $0.38 \mathrm{~mm}$ long, $0.50 \mathrm{~mm}$ wide; widest in posterior third; slightly narrowed to anterior angles, anterior angles obtusely rounded; a deep emargination in front of posterior angles; with deep lateral furrow and distinct central depression; within central depression an indistinct elevation; without punctation, but with distinct and deep microsculpture; surface matte. Elytra: $0.50 \mathrm{~mm}$ long, $0.55 \mathrm{~mm}$ wide; with three carinae on disc; without punctation, but with distinct 


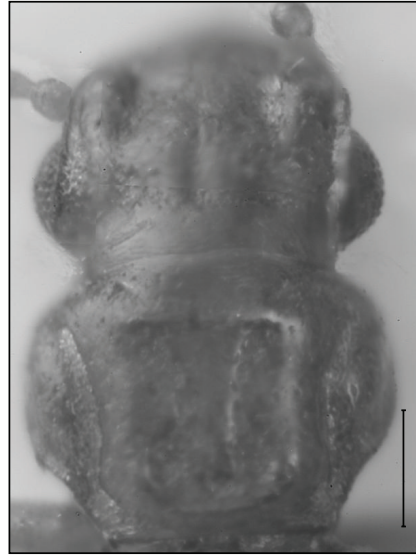

(a)

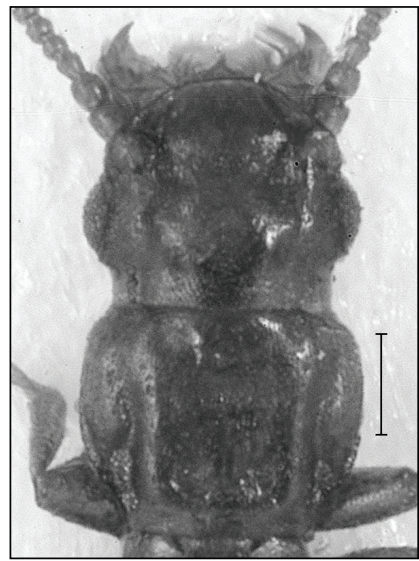

(c)

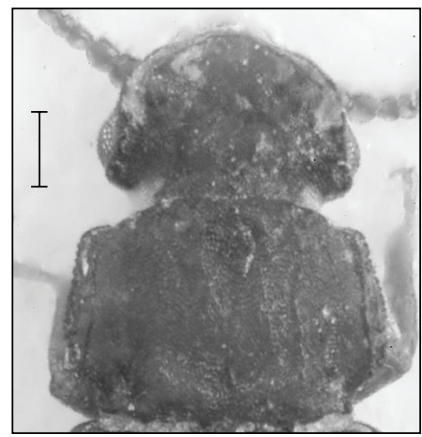

(e)

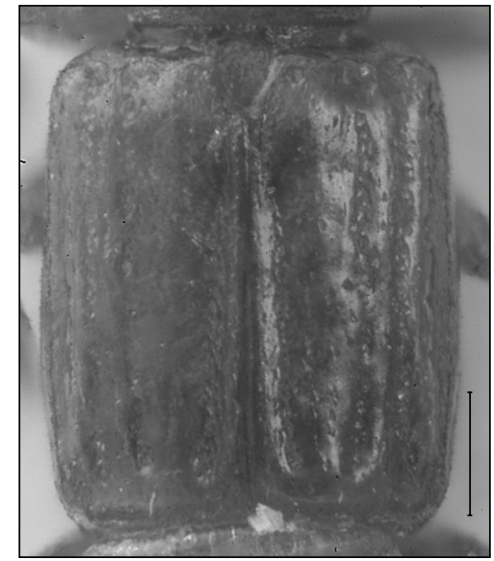

(b)

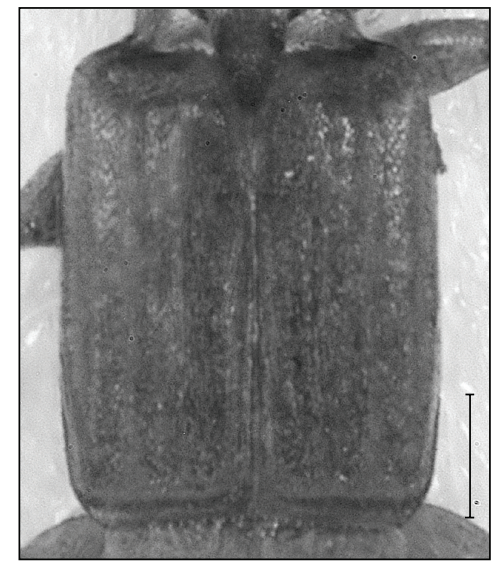

(d)

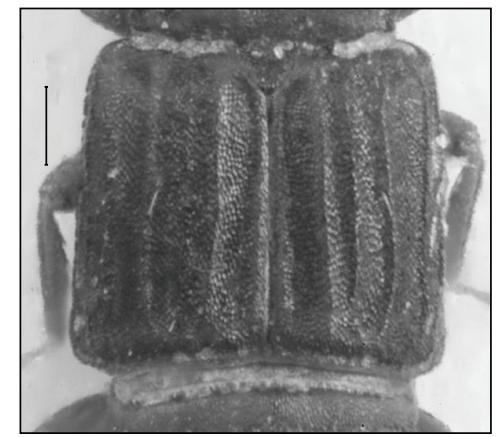

(f)

FIgURE 4: Surface of head, pronotum (a) and elytra (b) of Thoracophorus simplex; surface of head, pronotum (c) and elytra (d) of T. venezuelanus; and surface of head, pronotum (e) and elytra (f) of T. silvaticus (scale bar: $0.1 \mathrm{~mm}$ ).

and dense microsculpture, surface matte; microsculpture slightly less dense than on pronotum and head and, thus, surface slightly shiny. Abdomen without punctation, but with dense microsculpture, surface matte as on pronotum and head; tergites without striate structure, even at base of tergites; only with short and sparse setae laterally. Aedeagus form nearly rectangular angles between basic part and apical part; paramera as long as central lobe.

Etymology. The specific name is derived from the same Latin word meaning "living in the woods."

\section{Remarks on Ecology}

Thirty-six species of the genus Thoracophorus from the Neotropical region are known at present, including the two newly described ones here. According to Herman [6], 45 species of the genus are known worldwide. Thus, the Neotropical region is by far the most species-rich region in the world which, however, might be due to a better investigation status of the continent than of the African or Indo-Malaysian regions. Nevertheless, we are far from a more 


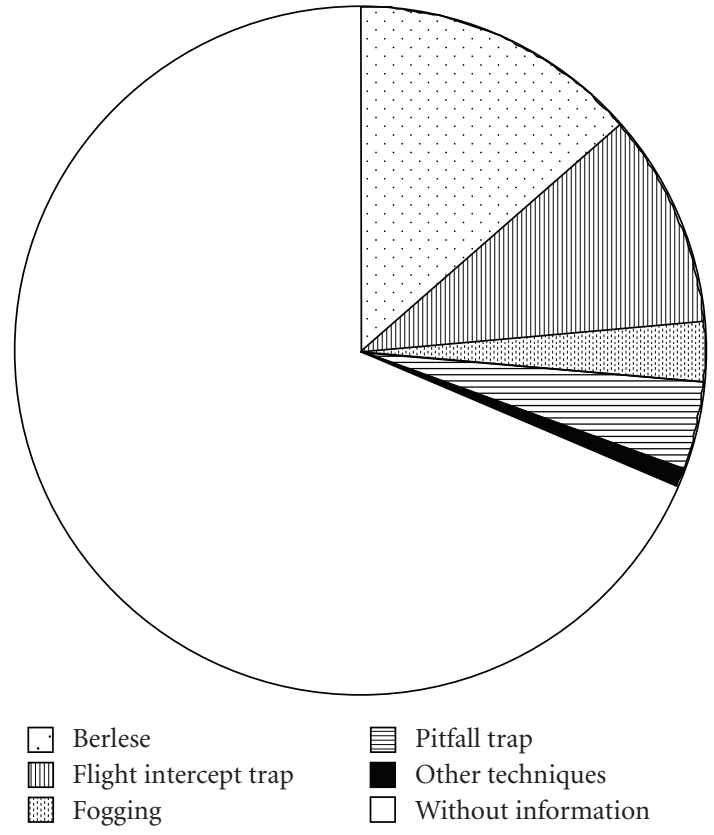

Figure 5: Fraction of specimens caught by different methods.

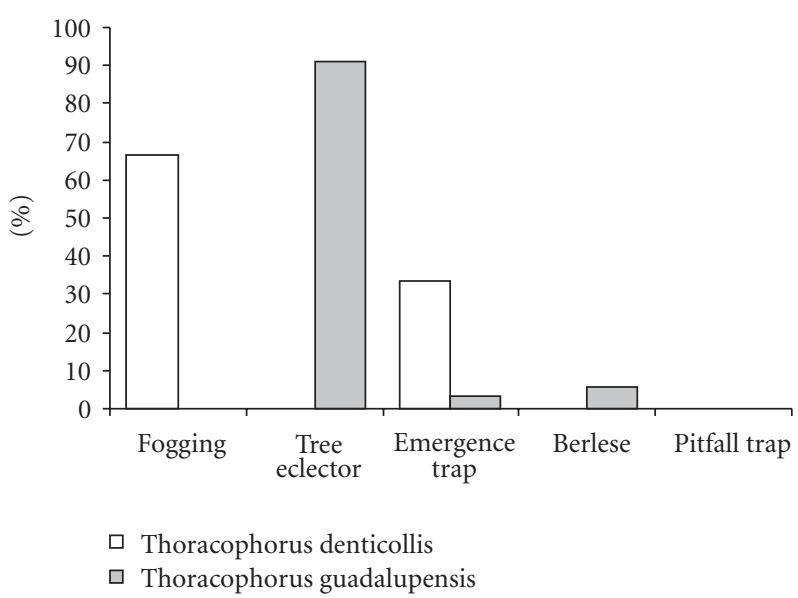

FIGURE 6: Fractions of specimens found by different methods in the Central Amazonian Varzea forest of Ilha de Marchanteria of the two Thoracophorus species.

or less complete knowledge of the species richness in the Neotropics.

The ecological requirements are known from only a few species. Regarding the information given by collectors on the pinned labels, nothing is known about 19 species except the location and sampling date. Two species, $T$. brevicristatus Horn, 1871 and T. heyeri Wasmann, 1902, live in nests of termites. T. brevicristatus can be regarded as an inquiline of Neotermes termites [7] and T. heyeri was found in nests of the termite Euthermes fulviceps [8]. Extraction of leaf litter and flight intercept trapping were the overall most efficient methods to capture Thoracophorus species (Figure 5). However, this differs between species. If specimens with no information on their collecting methods are omitted, T. aequalis Sharp, 1887 (86\%), T. exilis (Erichson, 1840) (78\%), T. filum Sharp, 1887 (67\%), and T. sculptilis (Erichson, 1840) (74\%) were mainly collected by flight intercept traps, whereas T. distinguendus Irmler, 2005 (79\%), T. guadalupensis (51\%), and T. susannae (63\%) were more efficiently caught by Berlese extraction from leaf litter.

The main habitat of the species can be derived from the specific methods that produced the highest numbers of species (Figure 6). According to the investigations performed by J. Adis in the Central Amazonian Varzea with different methods, T. denticollis (Erichson, 1840) $(n=3)$ was found by canopy fogging $(n=2)$ and trapping at tree trunks $(n=1)$, whereas $T$. guadalupensis $(n=784)$ was mainly caught by trapping at tree trunks, but was also taken in low abundances by litter extraction or by litter emergence traps, and even very rarely in pitfall traps $(n=1)$. It can be supposed that both species mainly inhabit the canopy or tree trunks and only rarely the soil floor. This is supported by investigations made by J. C. Hurtado in the terra firme forest of Reserva Ducke, located about $40 \mathrm{~km}$ north-east of Manaus, where several specimens of T. guadalupensis were found from March to May 1996 on Eschweilera wachenheimii (Benoist) Sandwith, 1932 and Corythophora alta Knuth, 1939 trees (material in Natural History Museum, London).

The most common species, T. guadalupensis, showed an abundance ratio of $27: 8: 0$ in the investigations in 1971 and 1972 in three inundation forests of white water, mixed water, and black water, respectively. Thoracophorus guadalupensis obviously preferred the nutrient and sediment rich site at Ilha de Curarí in the Varzea of the Rio Solimões. Regarding the seasonal occurrence of the species at Ilha do Curarí, most specimens occurred in the late half of the dry season in the upper zones of the Varzea forest up to $3 \mathrm{~m}$ inundation during the immersion period (Figure 7). This corresponds to an emersion period from mid-September to mid-March. An equally seasonal and zonal occurrence was found in the mixed water inundation forest at Lago Janauarí. In sites with longer and deeper immersion and shorter emersion periods, respectively, no specimens were found. According to the hand-sorting results, the abundance on the forest floor ranged from 3 ind $\cdot \mathrm{m}^{-2}$ to $14 \mathrm{ind} \cdot \mathrm{m}^{-2}$ at Ilha de Curarí and from 0.9 ind $\cdot \mathrm{m}^{-2}$ to 7.7 ind $\cdot \mathrm{m}^{-2}$ at Lago Janauarí during the late half of the emersion period.

\section{Discussion}

The biology of Neotropical Thoracophorus species is largely unknown, with the exception of two species that are certainly inquilines of termites $[7,8]$. Moreover, the sampling methods used to study these species provide no additional information about the living habitat of most species as records are mainly based on flight intercept traps or Malaise traps. The high number of records by Berlese extraction shows that the forest floor is used by many species, which is in concordance with the predatory Osoriinae genus Tannea that lives in the forest floor litter [9]. In contrast, the fungi-feeding genus 


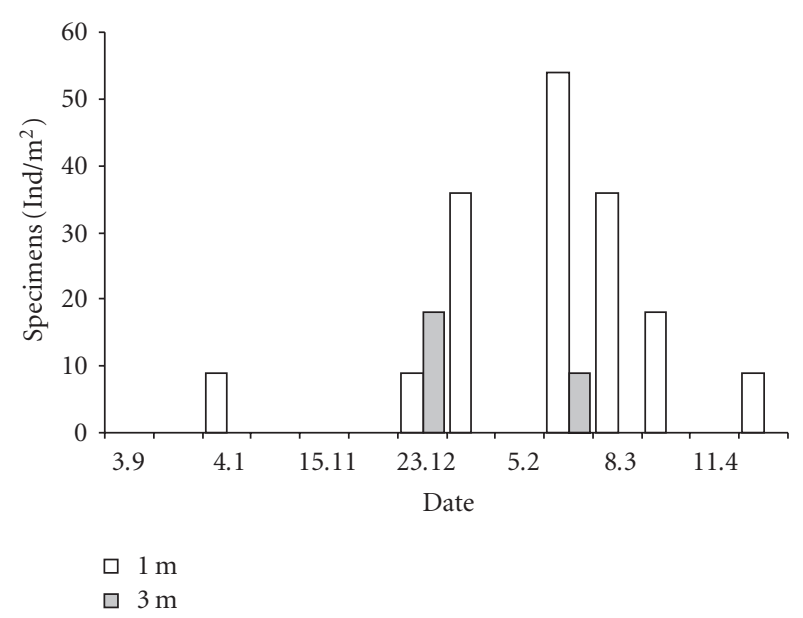

Figure 7: Abundance of Thoracophorus guadalupensis on forest floor during the dry period in the Varzea forest of Ilha de Curari at sites inundated 1 or $3 \mathrm{~m}$ during immersion period. No specimens were found at $4 \mathrm{~m}$ and $5 \mathrm{~m}$ immersed sites.

Lispinus nearly exclusively inhabits the under-bark habitat [10].

The example of T. guadalupensis indicates that species found in the litter layer mainly live on tree trunks, but apparently come to the forest floor in lower numbers. The lack of records from the tree trunk habitat in many species probably indicates the low investigation status of this habitat. Thus, tree trunks may be regarded to be a main habitat for species found on the ground as well. A different species from the Central Amazon, T. denticollis (Erichson, 1840), supports this hypothesis: the species was previously known from the type specimen from Puerto Rico, but was mainly found in the tree canopy of the Central Amazonian forest. The limited records of this species and the far distance between the two locations can be attributed to its canopy habitat which has hardly been investigated anywhere. Indeed, the fact that many Neotropical species are known from only a few specimens from flight intercept traps indicates that the upper tree zones in the rain forest are important habitats for many Thoracophorus species. Insects of upper zones in forests are generally organisms that fly well, as they have to move from tree to tree. During their flights, the species are generally caught by flight intercept traps or similar trapping methods. It is possible that more species of Thoracophorus are associated with ants or termites living in the canopy, on tree trunks, or on the ground of rain forests. In this case, records of Thoracophorus species on the soil floor can be referred to the larger habitat of their host species. Unfortunately, nothing is known about the host specificity of the species. The European Thoracophorus corticinus Motschulsky, 1837, is associated with the ant species Lasius brunneus [11]. However, the authors underlined the diversity of habitats and the opportunistic use of resources in the genus. If the canopy and tree trunk habitats are two of the main habitats of Thoracophorus species in the Neotropics, we may assume that the number of species will dramatically increase if these rarely-studied habitats will be investigated with more effort in the future.

\section{Acknowledgment}

This study is dedicated to the author's colleague and friend Professor Joachim Adis, who put his material on Central Amazonian rove beetles to the author's disposal and who passed away too early to publish the results together with him.

\section{References}

[1] U. Irmler, "Die Struktur der Carabiden- und Staphylinidengesellschaften in zentral-amazonischen Überschwemmungswäldern," Amazoniana, vol. 6, pp. 312-326, 1978.

[2] U. Irmler, "Neue Arten der Gattungen Aneucamptus und Thoracophorus (Col., Staphylinidae) aus der Neotropis," Entomologische Blätter, vol. 81, pp. 41-58, 1985.

[3] U. Irmler, "New Neotropical species of the genera Clavilispinus, Aneucamptus, Thoracophorus, and Holotrochus (Coleoptera: Staphylinidae, Osoriinae)," Amazoniana, vol. 16, no. 3-4, pp. 349-361, 2001.

[4] U. Irmler, "New Thoracophorus species from the Neotropical region (Coleoptera: Staphylinidae, Osoriinae)," Studies on Neotropical Fauna and Environment, vol. 40, no. 2, pp. 123127, 2005.

[5] J. Adis, "Terrestrial arthropods in soils from inundation forests and deforested floodplains of white water rivers in Central Amazonia," in The Central Amazon Floodplain: Actual Use and Options for a Sustainable Management, E. J. Junk, J. J. Ohly, M. T. F. Piedade, and M. G. M. Soares, Eds., pp. 463-476, Backhuys, Leiden, The Netherlands, 2000.

[6] L. Herman, "Catalogue of the Staphylinidae (Insecta: Coleoptera). 1758 to the end of the second millennium. II. Oxyteline group," Bulletin of the American Museum of Natural History, vol. 265, pp. 1067-1806, 2001.

[7] J. Bohàc, "Description of the larva and pupa of Thoracophorus brevicristatus (Coleoptera, Staphylinidae)," Acta Entomologica Bohemoslovakia, vol. 75, pp. 394-399, 1978.

[8] E. Wasmann, "Species novae Insectorum Termitophilorum ex America Meridionali," Tijdschrift voor Entomologie Nederlandse Entomologische Vereniging, vol. 45, pp. 5-107, 1902.

[9] U. Irmler, "The Tannea species of Costa Rica—new species and records, a key, geographical and ecological remarks," Brenesia, vol. 68, pp. 69-85, 2008.

[10] U. Irmler, "The genus Lispinus (Coleoptera: Staphylinidae: Osoriinae) in Costa Rica-a key, a new species, ecological and biogeographical remarks," Brenesia, vol. 66, pp. 1-13, 2006.

[11] B. Burakowski and A. Newton, "The immature stages and bionomics of the myrmecophile Thoracophorus corticinus Motschulsky, and placement of the genus," Annali del Museo Civico di Storia Naturale di Genova, vol. 89, pp. 17-42, 1992. 

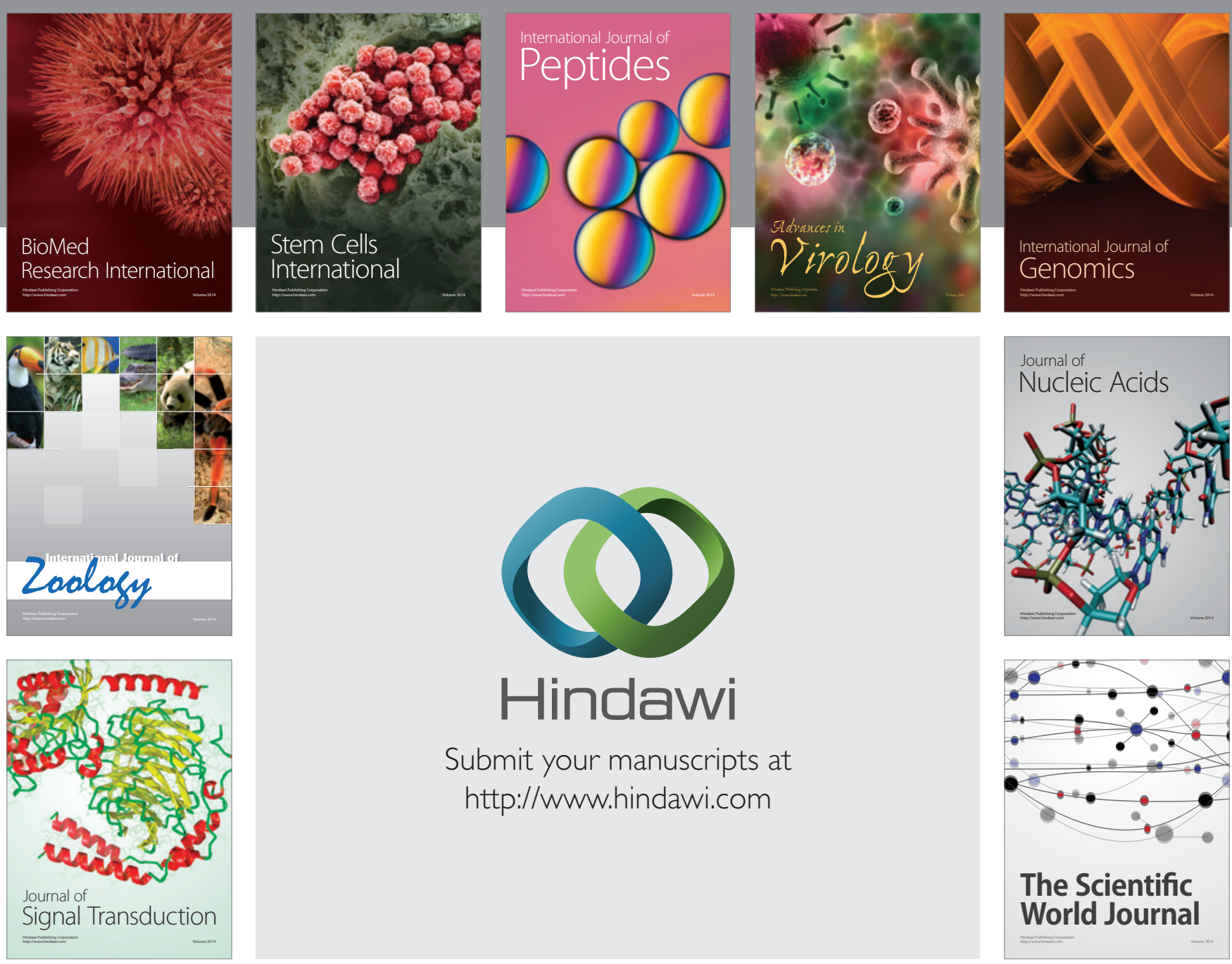

Submit your manuscripts at

http://www.hindawi.com
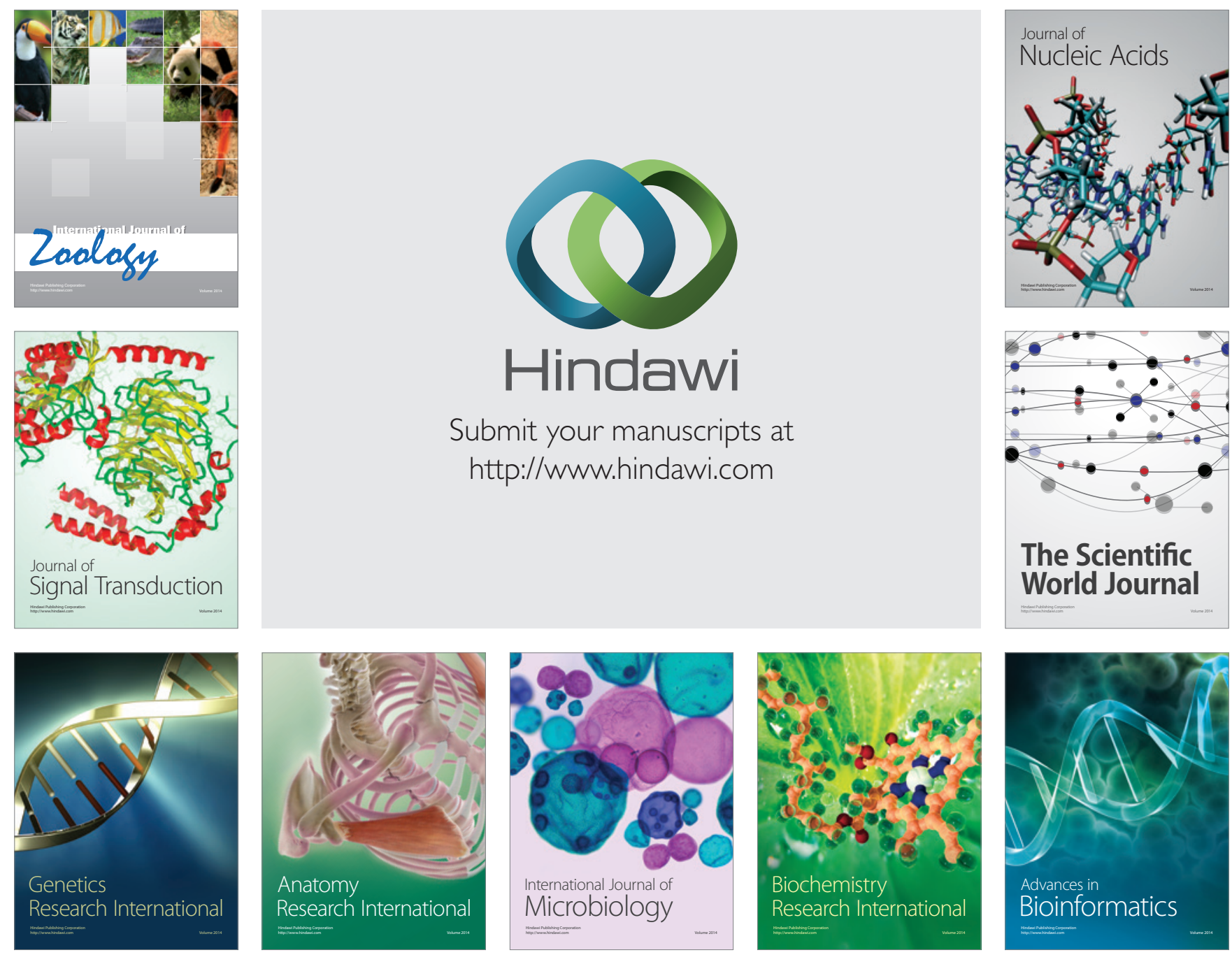

The Scientific World Journal
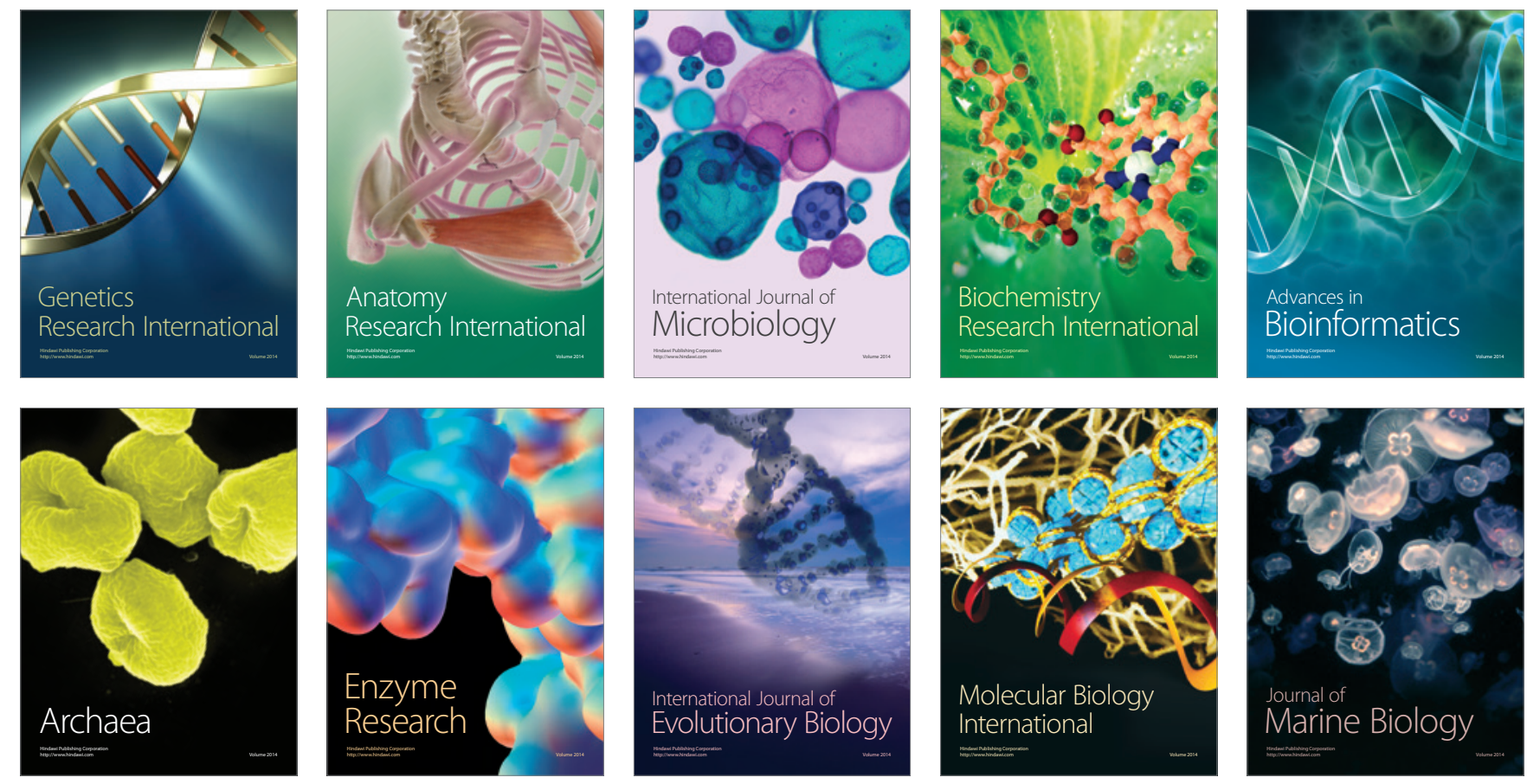